\title{
BIOGRAFI INTELEKTUAL SYEKH NAWAWI AL-BANTANI
}

\author{
Suwarjin \\ Fakultas Ushuluddin, Adab dan Dakwah IAIN Bengkulu \\ Jalan Raden Fatah Pagar Dewa Bengkulu \\ suwarjin@gmail.com
}

\begin{abstract}
Intellectual Biography Syekh Nawawi al-Bantani. The intellectual history of Indonesia has incised the world's major names, the most famous of which is Syekh Nawawi Banten. He has a very long education both in Indonesia and in some Arab countries. He successfully became a respected Indonesian scholar in the international world and led a colony in Makkah. The greatness of his name inspired many Indonesian students to study at Haramain. His greatest contribution in the field of education can be seen in the development of pesantren. He provides many teaching materials on the curriculum of pesantren through his works that still exist today. His students became scholars of pesantren who academically still preserve his thoughts. Among his students are also many who become leaders of resistance against invaders. The leaders of the Banten peasant rebellion of 1888 were his disciples, and so he was feared by the colonists.
\end{abstract}

Keywords: Biografi Intelektual, Syekh Nawawi Banten

Abstrak: Biografi Intelektual Syekh Nawawi al-Bantani. Sejarah intelektual Indonesia telah menorehkan nama-nama besar bertaraf dunia, yang paling terkenal di antaranya adalah Syekh Nawawi Banten. Ia menempuh pendidikan sangat panjang baik di Indonesia maupun di beberapa negara Arab. Ia sukses menjadi ulama Indonesia yang disegani di dunia internasional dan memimpin sebuah koloni di Makkah. Kebesaran namanya menginspirasi banyak pelajar Indonesia untuk menuntut ilmu di Haramain. Sumbangan terbesarnya dalam bidang pendidikan dapat dilihat pada pengembangan pesantren. Ia banyak menyediakan bahan ajar pada kurikulum pesantren melalui karya-karyanya yang hingga kini masih eksis. Murid-muridnya menjadi ulama-ulama pesantren yang secara akademik masih melestarikan pemikirannya. Di antara murid-muridnya juga banyak yang menjadi tokoh perlawanan terhadap penjajah. Para pemimpin pemberontakan petani Banten 1888 adalah murid-muridnya, karena itu ia sangat ditakuti oleh penjajah.

Kata kunci: Biografi Intelektual, Syekh Nawawi Banten

\section{Pendahuluan}

\section{A. Pengembaraan Intelektual Syekh Nawawi Banten}

Syekh Nawawi Banten dilahirkan di desa Tanara, Serang, Banten pada tahun 1230 H/1815 M. ${ }^{1}$ Ia meninggal dunia pada tanggal 25 Syawal 1314 H/1897 M. dalam usia 84 tahun. Nama lengkapnya adalah Abu Abd al-Mu'ti Muhammad Nawawi ibn Umar at-Tanari al-Jawi al-Bantani. ${ }^{2}$ Ia dilahirkan dalam keluarga yang saleh dan memiliki tradisi relijius sebagai keturunan dari keluarga raja-raja dan bangsawan kesultanan Banten. Ayahnya, KH. Umar bin Arabi adalah ulama dan penghulu desa Tanara dan juga pemimpin sebuah masjid di desa yang menjadi cikal-bakal berdirinya pesantren milik keluarganya. Dari pesantren inilah ia mengawali pendidikannya. ${ }^{3}$ Ibunya bernama Nyai Zubaidah, seorang wanita salehah dan taat beragama. Selama mengandung, Nyai Zubaidah tidak pernah berhenti berdo'a untuk anak pertamanya itu. ${ }^{4}$

Terlahir dari keluarga yang agamis dan dalam lingkungan yang menjadi pusat kesultanan sekaligus pusat penyebaran agama Islam di Banten, memberikan pengaruh positif bagi pertumbuhan intelektualnya. 
Kecerdasannya diwarisi dari orang tua dan para nenek moyangnya, yang merupakan orang-orang berpengaruh, baik dalam bidang agama, maupun pemerintahan ${ }^{5}$. Bakatnya menjadi orang alim sudah nampak sejak usia kanakkanak. Ia pertama kali belajar agama di bawah bimbingan ayah kandungnya, $\mathrm{KH}$. Umar, ketika berusia 5 tahun. Pelajaran yang mula-mula dia dapat adalah ilmuilmu dasar agama Islam dan bahasa Arab. Pengajaran dari sang ayah berlangsung selama 3 tahun, yaitu hingga berusia 8 tahun. ${ }^{6}$ Menurut Abdurrahman Mas'ud, peran ayahnya sebagai guru pertama bagi dia dan saudara-saudaranya merupakan tradisi masyarakat Muslim Jawa , di mana ayah menjadi orang pertama yang bertanggung jawab terhadap pendidikan anak-anaknya. ${ }^{7}$

Setelah merasa cukup pembelajaran bersama ayahnya, ia bersama dua orang saudaranya, Tamim dan Ahmad Syihabuddin, meminta do'a dan restu kepada ibunya untuk menuntut ilmu di pesantren lain. Nyai Zubaidah, ibunya, kemudian melepas kepergian mereka dengan berucap: “Kudo'akan dan kurestui kepergianmu mengaji dengan satu syarat; 'jangan pulang sebelum kelapa yang sengaja kutanam ini berbuah".

Ia dan kedua saudaranya belajar kepada Haji Sahal, seorang guru di Banten yang sangat terkenal kala itu. Dari Haji Sahal, mereka meneruskan studinya kepada Raden Haji Yusuf, 8 seorang ulama terkenal di daerah Purwakarta dekat Karawang. Snouck Hurgronje, seperti dikutip Amin, menyebut bahwa Raden Haji Yusuf adalah seorang ulama yang menarik perhatian dan antusiasme para pelajar yang berkelana dari seluruh Jawa, terutama dari daerah Jawa bagian Barat. ${ }^{9}$ Setelah menamatkan pelajaran kepada Raden Haji Yusuf, mereka mengirimkan surat kepada sang ibu untuk menanyakan apakah kelapa yang ditanamnya sudah berbuah. Karena tidak mendapat jawaban, mereka akhirnya memutuskan untuk tidak pulang terlebih dahulu. Mereka sepakat untuk melanjutkan pelajarannya di sebuah pesantren di Cikampek guna mendalami ilmu bahasa Arab. Di tempat yang baru itu mereka diuji terlebih dahulu oleh sang kiai. Mereka ternyata lulus dengan predikat sangat baik dan bahkan mereka diberitahu bahwa mereka tidak perlu lagi belajar di pesantren tersebut. Oleh sang kiai mereka bertiga disuruh pulang sebab, menurut sang kiai, pohon kelapa yang ditanam ibunya telah berbuah dan sang ibu telah menanti kepulangan mereka. Setelah sampai di rumah ternyata apa yang dikatakan oleh kiai tersebut benar, kelapa yang ditanam sang ibu telah berbuah dan dia sudah menanti kepulangan mereka. Menurut perkiraan, lamanya mereka menuntut ilmu adalah enam tahun. Hal ini didasarkan pada perkiraan bahwa pohon kelapa itu akan berbuah pada enam tahun sejak masa penanaman.10 Sampai sini ia telah mengenyam pendidikan selama lebih dari delapan tahun.

Dengan berbekal ilmu yang diperoleh dari ayahnya selama 3 tahun dan beberapa pesantren di sekitar Jawa Barat selama 6 tahun, kini saatnya ia mengajarkan ilmu itu kepada masyarakat di sekitar desanya. Kehadirannya membangkitkan gairah dan kepercayaan masyarakat sekitar. Sejak saat itu pesantren ayahnya menjadi ramai. Berbagai diskusi diselenggarakan secara 
rutin untuk membahas masalah-masalah agama. Para santri banyak mengajukan pertanyaan. Karena kepandaian menjawab pertanyaan-pertanyaan yang disampaikan para santri ayahnya, nama Syekh Nawawi Banten semakin terkenal dan mempesona banyak orang untuk datang dan belajar di pesantren ayahnya itu. ${ }^{11}$

Ketika ayahnya meninggal dunia, ia menggantikan posisinya sebagai pemimpin pesantren, meskipun saat itu usianya baru 13 tahun. ${ }^{12}$ Pesantren ayahnya semakin berkembang semenjak ia mengajar dan memimpin pesantren tersebut. Tentang hal ini Chaidar menjelaskan:

“Maka berdatanganlah para santri baru sehingga pesantren ayahnya di Tanara tidak lagi dapat menampung mereka. Oleh karena itu, Syekh Nawawi terpaksa mencari tempat yang memadai buat tuntutan kebutuhan. Dia memilih Tanara pesisir yang pada waktu itu masih sunyi sepi. Hijrahlah ia kesana, ke Tanara pesisir. Disebut Tanara pesisir karena letaknya di pantai."13

Namun demikian, keadaan ini hanya berlangsung dua tahun saja, sebab ia memutuskan untuk meninggalkan tanah airnya berhijrah ke Tanah suci dalam rangka memperdalam ilmu agama. ${ }^{14}$ Sambil melaksanakan ibadah haji ia menuntut ilmu di sana selama tiga tahun dan belajar kepada para guru kenamaan di Haramain, seperti Sayyid Ahmad an-Nahrawi, Sayyid Ahmad adDimyati dan Sayyid Ahmad Zaini Dahlan di Makkah, serta Syekh Muhammad Khatib al-Hanbali di Madinah. ${ }^{15}$ Sejumlah peneliti menjelaskan maksud dan alasan kepergiannya ke Haramain untuk pertama kalinya. Pertama, ingin melaksanakan ibadah haji. ${ }^{16}$ Bagi umat Islam saat itu, haji tidak sekedar berdimensi ibadah semata, tetapi merupakan konggres akbar umat Islam seluruh dunia. Dari konggres akbar ini, spirit pembaruan pemahaman terhadap Islam dan kesadaran akan pentingnya persatuan umat Islam seluruh dunia menggema dan menyeruak ke seluruh negeri Muslim yang kala itu hampir seluruhnya terjajah. Dan dari sini menggelora semangat perlawanan untuk mencapai kemerdekaan. Bagi orang-orang Eropa, ibadah haji sendiri merupakan sumber sosial bagi revitalisasi kehidupan agama Islam dan Makkah merupakan tempat persemaian fanatisme keagamaan dan penanaman rasa permusuhan terhadap penguasa-penguasa kristen di tanah air. ${ }^{17}$ Oleh karena itu, mereka yang pergi haji dianggap membahayakan buat keberadaan dan stabilitas pemerintah kolonial. ${ }^{18}$

Jumlah umat Islam yang pergi haji terus mengalami peningkatan dari tahun ke tahun, meskipun biaya yang dibutuhkan cukup besar.19 Statistik pemerintah Belanda melaporkan, antara tahun 1911-1914 persentase jamaah haji Indonesia mencapai 50 persen dari seluruh jamaah haji luar negeri. ${ }^{20}$ Meskipun pemerintah Belanda mempersulit perjalanan suci ini dengan menaikkan biaya perjalanan sampai berlipat-lipat, namun pada kenyataannya kebijakan ini tidak mampu menghambat keinginan mereka untuk pergi ke tanah suci, termasuk Syekh Nawawi Banten. Mereka yang berminat pergi haji oleh pemerintah kolonial Belanda dikenakan banyak aturan yang sangat menyulitkan, 
di antaranya bahwa setiap calon haji harus membayar 110 gulden hanya untuk pas jalan. Dan bagi yang melanggar ketentuan pas jalan ini akan dikenakan denda sebesar 1000 gulden. ${ }^{21}$

Kedua, menuntut ilmu agama Islam. Perjalanan haji saat itu membutuhkan waktu berbulan-bulan, sampai enam bulan lamanya. ${ }^{22}$ Syekh Nawawi Banten memanfaatkan perjalanan ini untuk menuntut ilmu. Ia menetap selama tiga tahun di sana guna mendalami ilmu agama. Baginya, menuntut ilmu adalah kewajiban setiap mukmin. Ia memandang usaha menuntut ilmu sebagai jihad $f_{i}$ sabïlilläh. Jika seseorang gugur sewaktu mencari ilmu, ia dianggap mati syahid. Doktrin inilah yang membentuk tradisi para santri untuk pergi mengembara dari pesantren ke pesantren lain dalam rangka memperluas cakrawala pengetahuan tentang Islam.

Secara khusus, semangat Syekh Nawawi Banten yang luar biasa untuk merantau demi menuntut ilmu pengetahuan, baik sewaktu di Jawa maupun di tanah Arab, terilhami oleh salah satu ungkapan Imam Syafi'i, yaitu:

“Tidak layak bagi orang yang berakal dan berilmu, beristirahat (dalam mencari ilmu). Tinggalkan negerimu dan berkelanalah, kelak engkau akan menemukan pengganti orang-orang yang engkau tinggalkan. Bersusah payahlah, karena sesungguhnya ketinggian derajat kehidupan hanya bisa dicapai lewat susah payah." 23

Dalam hal ini, Syekh Nawawi Banten bukanlah orang pertama yang merintis tradisi memanfaatkan ibadah haji untuk menimba ilmu keislaman. Sudah ribuan orang mendahuluinya. Pada waktu Snouck Hurgronje melakukan penelitian selama 6 bulan di Makkah, ia mencatat jumlah mahasiswa Indonesia di sana mencapai lebih dari 5.000 orang, mewakili 50 persen dari seluruh mahasiswa asing di Arab Saudi. ${ }^{24}$

Dengan melaksanakan ibadah haji dan menuntut ilmu di Mekah pada saat usia belia, Syekh Nawawi Banten telah memiliki dua modal sosial yang sangat penting, di samping faktor keturunannya. Kedua modal sosial inilah yang membantu perkembangan karir dan karismanya di kalangan umat Islam Indonesia. Bagi umat Islam Indonesia, haji juga merupakan gelar yang sangat terhormat, hampir menyamai gelar kiai. ${ }^{25}$

Setelah tiga tahun belajar ilmu agama di Mekah Syekh Nawawi Banten kembali ke kampung halamannya dan mengajar di pesantren milik ayahnya. Namun, kepulangannya ini tidak untuk menetap di Banten, sebab tidak terlalu lama setelah itu, ia meninggalkan Banten dan pergi ke Makkah untuk menetap selamanya di sana. ${ }^{26}$ Menurut para peneliti, kepergiannya untuk menetap selamanya di Mekah ini disebabkan oleh dua faktor, yaitu: karena ingin lebih mendalami ilmu agama Islam dan karena sangat tertekan oleh penjajah Belanda. ${ }^{27}$ Pendapat ini juga didukung oleh Harun Nasution dan C. Brockelmann yang mengatakan bahwa Syekh Nawawi Banten memutuskan untuk kembali ke Mekah dan menetap di sana lantaran merasa tidak betah tinggal di lingkungannya sendiri. ${ }^{28}$ Tentang hal ini, Ma'ruf Amin, seperti dikutip Amin, menyatakan: 
“Ketakutan penjajah terhadap pemuda Nawawi semakin besar ketika dijumpainya bahwa pengaruh anak muda ini semakin melebar di masyarakat. Pengawasan demi pengawasan terus ditingkatkan oleh pihak penjajah begitu melihat kenyataan bahwa perilaku pemuda Nawawi sanggup memobilisasi massa. Ceramah-ceramahnya dinilai oleh pihak penjajah bisa membangkitkan kesadaran masyarakat untuk bangkit melawan para kolonial. Begitulah keadaannya selama pemuda Nawawi berada di kampung halamannya." 29

Kebenciannya kepada penjajah ditunjukkannya saat Snouck Hurgronje berkesempatan mewawancarainya di Mekah. Bahkan, ia merasa bergembira ketika diberi tahu kesulitan-kesulitan yang dihadapi Belanda di Aceh. ${ }^{30}$ Sikapnya kepada Belanda sangat tegas, meskipun ayahnya, Umar Ibn 'Arabi dan adiknya, Ahmad menjabat sebagai penghulu desa, ia tidak hendak mengikuti jejak langkah ayah dan adiknya, untuk menjadi pegawai pemerintahan yang kafir. ${ }^{31}$

Kepergiannya untuk menetap selamanya di Mekah merupakan cerminan sikap politiknya yang anti terhadap penjajah. Sikap politiknya ini sangat mempengaruhi fatwa-fatwanya. Salah satu fatwa politiknya adalah diharuskannya setiap mukallaf untuk meninggalkan tempat kemaksiatan (mufäraqah maudidi al-ma'șiyyah) dan tempat-tempat terjadinya keburukan (majālis as-sü'), seperti tempat kecurangan, kebatilan dan tempat di mana praktik suap-menyuap dikerjakan. ${ }^{32}$ Fatwa ini sangat jelas hubungannya dengan kondisi Indonesia pada umumnya dan Banten pada khususnya saat berada di bawah kolonialisme. Praktik-praktik kemaksiatan sebagaimana disebutkan Syekh Nawawi Banten di atas adalah nyata adanya dan sudah menjadi sesuatu yang lumrah.

Seperti diketahui, Pada abad ke XIX, di mana Syekh Nawawi Banten lahir dan tumbuh menjadi dewasa, kondisi Banten sangat memprihatinkan, akibat tekanan dari pemerintah kolonial Belanda. Eksploitasi hasil bumi dan monopoli perdagangan yang dilakukan Belanda membuat rakyat Banten hidup dalam kepungan kemiskinan. Ditambah lagi sistem kerja paksa dan pajak kepala yang diberlakukan pemerintah kolonial Belanda membuat penderitaan rakyat Banten semakin tak terperikan. ${ }^{33}$ Semua itu mendorongnya untuk meninggalkan tanah air guna menuntut ilmu dan membangun spirit perlawanan terhadap penjajah Belanda melalui ilmu dan pemikirannya. Spirit perlawanan terhadap penjajah ini didasarkan pada pijakan normatif yang ia pegang teguh, yaitu Sabda Nabi: "Barang siapa mengetahui adanya kemungkaran, hendaklah merubahnya dengan kekuatannya, jika tidak sanggup, dengan lisannya, jika tidak sanggup dengan hatinya, dan inilah iman paling lemah." 34

Ia berpendapat bahwa orang yang mampu merubah kemungkaran dengan kekuasaannya, tidak boleh melakukan dengan lisannya, dan orang yang mampu dengan lisan, tidak boleh dengan hatinya. ${ }^{35}$ Sementara orang yang hanya mampu melawan dengan hatinya, tetapi ia tak melakukannya, maka ia berarti ridha terhadap kemaksiatan, dan ridha terhadap kemaksiatan adalah sikap kontra 
terhadap iman. ${ }^{36}$ Ia sendiri melakukan perlawanan melalui ceramah dan lisan 'penanya' yang sangat tajam. Melalui pena dan pengajarannya ia mengobarkan semangat perlawanan terhadap penjajah. Karena gencarnya propaganda anti penjajah yang ditanamkan pada muridmuridnya, pemerintah kolonial Belanda mengutus Snouck Hurgronje untuk mengawasi sepak terjang Syekh Nawawi Banten di Mekah. ${ }^{37}$

Saat itu, intervensi penjajah belanda sudah menusuk ke jantung kehidupan beragama umat Islam Nusantara. Burger, seperti dikutip Ibnu Qoyim Isma'il, mencatat empat tahap intervensi pemerintah kolonial untuk merubah masyarakat Jawa yang bersifat feodal tradisional menuju masyarakat kolonial modern. ${ }^{38}$ Tahap pertama, merebut dan menguasai pasar perdagangan; tahap kedua, mulai tahun 1800-an membentuk pusat pemerintahan kolonial dan melakukan program tata bumi hingga tahun 1830-an; tahap ketiga, menerapkan program/sistem tanam paksa (culture stelsel) sampai dengan tahun 1870-an; dan tahap keempat, mulai melaksanakan politik kolonial modern, termasuk regulasi dalam bidang sosial budaya dan kehidupan keagamaan.

Kebijakan pemerintah kolonial, baik yang menyangkut politik, maupun hukum sangat dirasakan dampaknya oleh umat Islam Indonesia. Mereka berusaha menghalangi tumbuh dan berkembangnya Islam di Indonesia, serta menghambat pelaksanaan ajaran agama. Campur tangan Belanda dalam bidang agama, dimulai dengan upaya menjauhkan umat Islam dari agama mereka. Pemerintah kolonial membangun sekolah-sekolah
Modern ala Barat dan mendidik para pelajar pribumi dengan pendidikan Barat. Setelah itu mereka mulai masuk pada aspek politik hukum, yaitu dengan memasukkan bidang agama ke dalam sistem tata pemerintahan dan mengangkat para pegawai dari umat Islam. Tujuannya adalah agar gerak-gerik umat Islam dapat diawasi melalui para pegawai tersebut.

\section{B. Karier Akademik Syekh Nawawi Banten}

Syekh Nawawi Banten mengenyam pendidikan di Timur Tengah dalam waktu sangat lama antara tahun $1830-1860 .{ }^{39} \mathrm{Di}$ sana, ia belajar pada guru-guru ternama. Pertama kali beliau mengikuti bimbingan dari Syeikh Ahmad Khatib Sambas (Penyatu Thariqat QodiriyahNaqsyabandiyah di Indonesia) dan Syekh Abdul Gani Bima, ulama asal Indonesia yang bermukim di sana. ${ }^{40}$ Snouck Hurgronje menyebutkan bahwa Syekh Nawawi Banten pernah belajar kitab Ihyya $\bar{a}^{\prime}$ Ulüm ad-Din karya al-Ghazali kepada asSambasi. Setelah itu belajar pada Sayid Ahmad Dimyati, Ahmad Zaini Dahlan di Mekah. Sedang di Madinah, ia belajar pada Muhammad Khatib al-Hanbali. Kemudian melanjutkan pelajarannya pada ulama-ulama besar di Mesir dan Syam (Syiria). Menurut penuturan Abdul Jabbar, seperti dikutip Zamakhsyari Dhofier, sebagian guru utamanya pun berasal dari Mesir, yaitu Syekh Yusuf Sumbulawini dan Syekh Ahmad Nahrawi. ${ }^{41}$ Sri Mulyati menyebut kedua orang guru berkebangsaan Mesir inilah guru sebenarnya dari Syekh Nawawi Banten, ${ }^{42}$ selain Abdul Hamid Daghastani. ${ }^{43}$ 
Sebelum ke Timur Tengah ia berguru ke beberapa pesantren di Jawa Barat sampai kurang lebih 9 tahun lamanya. ${ }^{44} \mathrm{Jadi}$, ia menghabiskan waktu sekitar 39 tahun untuk menuntut ilmu. Masa studi yang begitu panjang menjadikannya seorang 'alim terkemuka. Ia menguasai sebagian besar cabang ilmu keislaman. ${ }^{45}$ Sejak masih di Indonesia ia telah menunjukkan bakat akademik yang sangat cemerlang, sehingga menarik perhatian orang banyak.

Berbekal ilmu yang sangat luas itu, Syekh Nawawi Banten kemudian menjadi guru yang sangat disegani. Muridnya datang dari berbagai penjuru dunia. Namun, kebanyakan dari mereka adalah para pelajar asal Melayu. Puncak kariernya sebagai seorang guru ia raih tatkala ia dipercaya mengajar di Masjidil Haram. Setiap ia mengajar, murid-murid yang mengikuti perkuliahannya tidak kurang dari 200 orang. Masjidil Haram pada saat itu adalah satu-satunya perguruan tinggi di Makkah. Di ma'had Nasyr al-Ma'ārif ad-Dīniyah yang berada di komplek Masjidil Haram, ia terkenal sebagai guru yang baik hati, mampu menjelaskan pelajaran secara baik dan mendalam, dan berkomunikasi secara baik dengan para muridnya. ${ }^{46}$

Setelah mengajar di Masjidil Haram selama sepuluh tahun (1860-1870), akhirnya pada tahun 1870 ia memilih istirahat. Ia lebih berkonsentrasi untuk menulis kitab. ${ }^{47}$ Namun demikian, bukan berarti ia berhenti mengajar, sebab mengajar baginya merupakan kewajiban agama yang tak mungkin ditinggalkan. Ia melanjutkan pengajarannya di rumah. Menurut Snouck Hurgronje, ia memberikan kuliah kepada murid- muridnya di sebuah ruangan yang luas sekali di lantai pertama rumahnya. Setiap hari dia mengajar antara jam 7.30-12.00. pengajaran tersebut dibagi dalam tiga perkuliahan yang disesuaikan dengan kebutuhan murid-muridnya. ${ }^{48}$

Seperti umumnya kiai di Jawa, Syekh Nawawi Banten memberikan pelajaran dengan sistem bandongan. Dalam sistem ini, sekelompok murid (antara 5-500 orang) mendengarkan sang guru membaca, menerjemahkan, menerangkan, dan mengulas buku-buku Islam berbahasa Arab. Setiap murid menyimak bukunya sendiri dan membuat catatan seperlunya terkait dengan arti maupun keterangan mengenai kata-kata atau buah pikiran yang masih perlu penjelasan. Dalam sistem bandongan ada yang disebut halaqah, yaitu lingkaran murid atau sekelompok siswa yang belajar di bawah bimbingan seorang guru. ${ }^{49}$

Ia menulis tidak kurang dalam sembilan disiplin ilmu, meliputi tafsir, fikih, ushuluddin, ilmu tauhid (teologi), tasawuf (mistisisme), kehidupan Nabi (sirah nabawiyah), tata bahasa Arab, hadis, dan akhlak (ajaran moral Islam).50 Menurut penuturan Chaidar, pilihannya menulis berbagai disiplin ilmu didasarkan atas keinginannya untuk memenuhi kebutuhan dan kepentingan hidup umat Islam, baik secara individu maupun masyarakat.51 Kitab-kitabnya sangat berpengaruh di Indonesia. Bahkan secara agak berlebihan Chaidar menggambarkan bahwa kita dapat mengenal syarat dan rukun nikah karena jasa Syekh Nawawi Banten. ${ }^{52}$ Ia menulis kitab dengan bahasa Arab pada saat ulama-ulama Arab sendiri tidak menghasilkan karya yang patut dibanggakan. ${ }^{53}$ Nilai karyanya yang tinggi 
makin membubungkan namanya di dunia Melayu maupun Arab.54 Hampir satu setengah abad lamanya kitab-kitab karyanya bertahta di atas arasy pemikiran tradisi keilmuan pesantren. Hingga kini, karya-karyanya masih dipelajari di berbagai pesantren di Indonesia. ${ }^{55}$

Mengenai jumlah karyanya para peneliti berbeda pendapat. Menurut Abdurrahman Wahid karyanya mencapai lebih dari 100 buah, ada yang menghitungnya 40 buah, meskipun tidak ada satu peneliti pun yang dapat menunjukkan seluruh judul kitab-kitab yang dikarangnya. Bruinessen, dalam penelitiannya, hanya mampu mengidentifikasi 22 kitab karya Syekh Nawawi Banten. ${ }^{56}$ Di samping meneladani para pendahulunya, ${ }^{57}$ inisiatif menulis banyak datang dari desakan para kolega, sahabat atau murid yang memintanya menulis kitab syarh. ${ }^{58}$ Kebanyakan permintaan itu datang dari sahabat beliau yang berasal dari Jawa,59 karena dibutuhkan untuk dibacakan kembali di daerah asalnya. Desakan itu dapat terlihat dalam setiap karyanya yang sering mencantumkan alasan penulisan kitabnya.

Meskipun bermukim di Makkah, kecintaannya pada tanah air, dan empatinya terhadap penderitaan yang dialami oleh penduduk bangsanya tidak pernah surut. Ia tak lupa menanamkan semangat perlawanan kepada penjajah guna membebaskan penduduk Indonesia dari cengkraman kaum penjajah. Ajarannya secara tidak langsung mempengaruhi gerakan-gerakan Islam di Jawa Barat melawan kolonial Belanda. ${ }^{60}$ Hal ini terbukti, sebagian muridnya menjadi tokoh perlawanan, seperti Haji Wasith dan Haji Tubagus Ismail, pemimpin pemberontakan Cilegon 1888.61 Namun, pengaruh Syekh Nawawi Banten tidak hanya di daerah asalnya, dikarenakan kitab-kitab yang dia tulis dan didedikasikan di Mekah kepada pelajar Indonesia yang datang dari berbagai tempat yang jauh. Karena kitab-kitabnya menjadi teks utama di pesantrenpesantren, dan karenanya komunitas pesantren memandangnya sebagai pahlawan muslim Jawa di Arab pada abad XIX. Misi pesantren menjadi sangat efektif ketika menggunakan istilah-istilah simbolik, seperti: 'perang suci mengusir orang-orang kafir. Ajaran-ajarannya dalam masalah ini telah membentuk perspektif politik di kalangan komunitas pesantren untuk mempertahankan negerinya dari pengaruh kekuasaan asing, ${ }^{62}$ yang kafir. Muridnya yang lain juga menjadi pejuang kemerdekaan, seperti Hadhratus Syekh Hasyim Asy'ari, salah satu tokoh pejuang kemerdekaan. Ia bukan sekedar hamba ilmu yang tak peduli dengan permasalahan sosialpolitik, tetapi menggunakan ilmu untuk memanusiakan manusia, yang salah satu bentuknya adalah untuk melawan penjajahan yang merendahkan martabat manusia yang sejatinya dimuliakan oleh Allah.

\section{Murid Syekh Nawawi Banten}

Di antara murid-muridnya dari Indonesia yang kemudian menjadi pimpinan pesantren adalah kiai Khalil Bangkalan, Madura, Hadhratus Syeik Hasyim Asy'ari, KH Ilyas Serang, Banten, KH. Tubagus Muhammad Asnawi Caringin, Jawa Barat, KHR Asnawi Kudus. mereka memiliki peran besar dalam menyebarluaskan pemikiran Syekh 
Nawawi Banten melalui kitab-kitab karyanya. Dalam hal ini, ia lebih diuntungkan dibanding ulama Indonesia lainnya, karena murid-muridnya membantu penyebarluasan kitabkitabnya. Hampir seluruh muridnya menjadi pendiri dan pemimpin pesantren besar di Indonesia. Melalui pesantren masing-masing, para murid ini mengajarkan kitab-kitab karya sang Syekh kepada murid-murid mereka. Setelah tamat dari pesantren, para murid ini menyebar ke berbagai daerah di Indonesia dan mendirikan pesantren di tempat mereka masing-masing. Di pesantrenpesantren yang mereka dirikan ini, para murid juga mengajarkan kitab-kitab sang Syekh dan demikian seterusnya. Dari sini, pemikiran fikih Syekh Nawawi dapat ditransmisikan ke seluruh pelosok nusantara melalui jaringan yang terbentuk antara guru dan murid.

\section{Deskripsi Singkat Karya-Karya Syekh Nawawi Banten}

Sebagian dari karya-karya Syekh Nawawi Banten belum diterbitkan dan sebagian lagi tidak sampai kepada kita. Berikut akan diberikan deskripsi singkat tentang karya-karyanya yang telah terbit berdasarkan bidang keilmuan yang menjadi konsennya:

\section{Bidang Tafsir}

Dalam bidang tafsir Nawawi hanya menulis satu buah kitab, yaitu Tafsîr al-Munîr li Ma'âlim al-Tanzîl atau Marâh Labîd li Kasyf Ma'nâ al-Qur'ân alMajîd, ${ }^{63}$ yang terdiri dari dua jilid. Kitab ini sangat dikagumi oleh ulama di Makkah dan Mesir dan juga banyak digunakan di pesantren-pesanten di Indonesia. Tafsir ini menjadi terkenal, karena lahir pada masa kelesuan tradisi kepengarangan yang melanda umat Islam. Masa ini, tidak menghasilkan satu pun karya monumental dalam bidang tafsir, selain apa yang dihasilkan oleh Syekh Nawawi Banten .

Ia menyelesaikan penulisan tafsirnya ini pada tahun 1886. Sebelum diterbitkan karyanya ini dikirimkan kepada para ulama terkemuka di bidangnya untuk dibaca dan dikoreksi. Hal ini memberi bobot tersendiri karena karyanya ini telah mendapat legitimasi dari para pakar tafsir pada zamannya. Namun demikian, ia menyadari betul bahwa karyanya sama sekali tidak akan mampu menyamai karya ulama terdahulu, namun ia yakin bahwa pada setiap periode harus ada pergantian dan pembaruan. ${ }^{64}$ Pernyataan ini menegaskan kesadarannya akan kebenaran sabda Nabi bahwa dalam setiap kurun waktu 100 tahun Allah pasti mengutus hambahamba-Nya yang terpilih untuk memperbarui pemahaman dan pengamalan ajaran agama-Nya. Meskipun tafsirnya belum dapat dikatakan sebagai tafsir modern, namun di dalamnya telah mengandung unsur-unsur pembaruan. Karena itu, tafsir Nawawi dapat dikatakan sebagai jembatan penghubung antara tafsir klasik dan tafsir modern. ${ }^{65}$

2. Bidang Tasawuf dan Ahlak

Dalam muqaddimah kitab Nihāyah az-Zein fi Irsyād al-Mubtadi'inn, Syekh Nawawi menjelaskan bahwa setiap orang yang tidak memiliki kemampuan berijtihad harus bertaqlid, baik secara teoritis, maupun praktis kepada salah satu imam tasawuf, seperti imam al-Junaid. ${ }^{66}$ Ia sendiri menyatakan diri sebagai murid dari Syekh Ahmad Khatib Sambas, 
penyatu antara tarekat Qadiriyah dan Naqsyabandiyah. Dalam pengamalan tasawuf ia mengikuti tarekat Qadiriyah. Hal ini dinyatakannya di dalam muqaddimah kitab Syarh Bahjah alWasā'il.67 Namun demikian, ia tidak memimpin suatu tarekat sebagaimana gurunya, al-Sambasi. Sikapnya terhadap tarekat tergolong moderat, ia tidak menganjurkan dan tidak melarang muridmuridnya mengikuti tarekat tertentu. Namun demikian, sebagian besar muridnya dari Indonesia menjadi guruguru tarekat yang sangat terkenal, seperti kiai Khalil Bangkalan dan kiai Hasyim Asy'ari.

Dalam bidang tasawuf, Syekh Nawawi menulis beberapa kitab yang seluruhnya dalam bentuk syarah (penjelasan). Kitab-kitab tasawuf tersebut mencerminkan pandangannya dan kedalaman ilmunya dalam bidang tasawuf. Setidaknya ada empat kitab dalam bidang ini yang beliau tulis, yaitu Miṣbāh az-Zalām atau Nūr az-Zalām, Qāmi' at-Tugyān, Bidāyah al-Hidāyah dan Salāilim al-Fudalā'. Kitab-kitab tersebut dipelajari secara luas di pesantren-pesantren Jawa.

3. Bidang Fikih atau Hukum Islam

Karya Syekh Nawawi dalam bidang fikih merupakan karya yang paling menonjol dibanding karyakaryanya pada bidang yang lain. Ia menulis tidak kurang dari 8 buah kitab fikih yang sampai saat ini masih dikaji di sejumlah pesantren. Uraiannya yang mendalam dengan gaya bahasa yang mudah dipahami, serta kandungannya yang sesuai dengan mazhab yang dianut mayoritas umat Islam Indonesia menjadikan karyanya di bidang ini tetap survive di tengah-tengah banyaknya karya-karya baru yang muncul setelah masa beliau. Karya fikih ini ditulis pada masa peralihan dari masa klasik ke masa modern. Karena itu, fikihnya mencerminkan karakteristik dua masa tersebut sekaligus. Namun demikian, faktor yang paling menentukan survivalitas karya beliau adalah watak tradisionalnya yang sesuai dengan watak umat Islam Indonesia.

Dari karya-karyanya dapat diketahui dua kecenderungan pemikiran fikih Nawawi. Pertama; pemikiran fikihnya sangat cenderung pada tasawuf. Kecenderungan ini sangat masuk akal, mengingat Islam yang dibawa masuk ke Indonesia adalah Islam yang bercorak tasawuf. Jadi, sejak pertama pekenalannya dengan ilmu fikih, Syekh Nawawi telah menerima pelajaran fikih yang bercorak tasawuf. Kedua; pemikiran fikih syekh Nawawi cenderung kontekstual. Ini dapat dilihat pada fatwanya tentang keharaman tinggal serumah dengan orang yang berbuat maksiat dan keharaman melakukan pemukulan berlebihan kepada anak dalam proses pendidikan.

Karya Syekh Nawawi dalam bidang fikih yang sampai saat ini masih dikaji oleh kalangan pesantren adalah kitab (1) Nihāyah al-Zein fi Irsyād alMubtadi'in, (2) Qūt al-Habìb al-Gharìb Tausyīh 'alā Fath al-Qarīb al-Mujīb, (3) Mirqāh Șu'ûd at-Tașdīq, (4) Syarh Sullam alMunājāt, (5) Kāsyifah as-Sajā fi Syarh Safinah an-Najā, (6) Syarh ar-Riyād al-Badī'ah bi asंSimār al-Yāni'ah, (7) Syarh Bahjah al-Wasā'il dan (8) Syarh Uqūid al-Lujain fi Bayān Huqūq az-Zaujain.

4. Bidang Tauhid

Dalam bidang tauhid, Syekh Nawawi Banten mengikuti paham yang dikembangkan oleh Abu Hasan al-Asy'ari. 
Dalam kitabnya, Fath al-Majid beliau berkali-kali merujuk kepada al-Asy'ari dengan menyebutnya sebagai syekh. Pada dasarnya, ia mengidentifikasi dirinya sebagai pengikut asy'ari dalam term-term i'tiqad.68 Dalam kitabnya, Nihāyah, ia menegaskan pandangannya bahwa siapapun yang bukan ahli dalam bidang ini, maka wajib baginya untuk bertaqlid pada imam Abu Hasan al-Asy'ari atau Abu Manshur al-Maturidi. ${ }^{69}$

\section{E. Penutup}

Sejarah intelektual memiliki sumbangan yang amat penting bagi perkembangan bangsa. Dari sejarah intelektual diketahui tahap-tahap perkembangan intelektual suatu bangsa yang memiliki karakteristik khas, berbeda dengan perkembangan intelektual bangsabangsa lain di dunia. Pesantren sebagai salah satu sub kultur, memiliki peran penting dalam perkembangan bangsa. Pesantren telah berkiprah sepanjang sejarahnya dalam membangun bangsa, utamanya dalam menyiapkan generasi intelektual yang memiliki komitmen kebangsaan kuat. Saat ini pesantren tetap eksis di tengah terpaan kemajuan dunia pendidikan yang semakin deras. Bahkan kini pendidikan pesantren telah dijadikan sebagai role model bagi pengembangan pendidikan di Indonesia. Pesantren akan terus eksis selama para tokoh pesantren tetap merawat warisan para guru intelektual pesantren. Dengan demikian, pesantren dengan komunitasnya, akan mampu memberikan sumbangan yang lebih besar terhadap kemajuan bangsa.

\section{Referensi}

1Zamakhsyari Dhofir, Tradisi Pesantren Studi Pandangan Hidup Kyai dan Visinya mengenai Masa Depan Indonesia,(Jakarta: LP3ES, 2011), 132.

${ }^{2}$ M. Bibit Suprapto, Ensiklopedi Ulama Nusantara Riwayat Hidup, Karya dan Perjuangan 157 Ulama Nusantara, (Jakarta: Gelegar Media Indonesia, 2010), 653.

3Syamsul Munir Amin, Sayyid Ulama Hijaz Biografi Syaikh Nawawi al-Bantani, (Yogyakarta: LkiS, 2009), 19.

${ }^{4}$ Ibid., 19-20.

${ }^{5}$ Ibid., 16.

6 Ibid., 20

${ }^{7}$ Abdurrahman Mas'ud, Dari Haramain ke Nusantara Jejak Intelektual Arsitek Pesantren, (Jakarta: Kencana Prenada Media Group, 2006), 110.

8 C. Snouck Hurgronje, Mekka in The Latter Part of 19TH Century Daily Life, Customs And Learning the Muslim of the East Indian Archipelago, (Leiden: Late E. J. Brill LTD, 1931), 268.

${ }^{9}$ Amin, Sayyid Ulama, 20.

10 Ibid., 20-21

11 Ibid., 22.

12 Ibid.

13 Chaidar, Sejarah Pujangga Islam Syaikh Nawawi al-Bantani Indonesia, (Jakarta: CV Sarana Mulia, 1978), 30.

14 Ibid., 5. Lihat juga Amin, Sayyid Ulama, 23. Lihat juga Mas'ud, Dari Haramain, 111.

${ }^{15}$ Ibid.

${ }^{16}$ Mas'ud, Intelektual, 97. Lihat Juga

Amin, Sayyid Ulama, 24.

17Ibnu Qoyim Isma'il, Kiai Penghulu Jawa Peranannya di Masa Kolonial, (Jakarta: Gema Insani Press, 1997), 42.

${ }^{18}$ Amin, Sayyid Ulama, 25.

${ }^{19}$ Biaya yang diperlukan untuk menunaikan ibadah haji dalam sekali jalan bervariatif, namun secara umum diketahui bahwa harga tiket standar pada masa penjajahan Belanda adalah f. 110 ditambah dengan jasa perusahaan dan syekh sebesar $f$. 17,5, maka jumlah ongkos yang harus dikeluarkan sebesar f. 127,5. Dalam ketentuan umum yang diminta oleh pemerintah Hindia Belanda bahwa setiap calon jamaah harus menyetor uang sebesar f. 500 dan jika terdapat uang lebih dari ongkos yang ditentukan akan 
dikembalikan kepada jamaah. (M. Dien Majid, Berhaji di Masa Kolonial, 55).

${ }^{20}$ Dhofier, Tradisi, 67.

21 Steenbrink, Beberapa Aspek, 236.

22 M. Dien Majid, Berhaji di Masa

Kolonial, (Jakarta: CV Sejahtera, 2008), 51.

${ }^{23}$ Amin, Sayyid Ulama, 27.

${ }^{24}$ Dhofier, Tradisi, 69.

${ }^{25}$ Bagi umat Islam di Banten saat itu, gelar haji memiliki status sosial yang sangat tinggi. Orang yang pulang haji umumnya dipandang memiliki kesalehan tinggi dan memiliki kesaktian tersendiri yang membuatnya sangat disegani dan sangat berpengaruh.

${ }^{26}$ Amin, Sayyid Ulama, 26.

27 Chaidar, Pujangga, 40.

28 Amin, Sayyid Ulama, 24.

${ }^{29}$ Ibid., 30-31.

30 Steenbrink, Beberapa Aspek, 120.

31 Ibid.

32 Syekh Nawawi Banten, Mirqāh, 16.

33 Sartono, Pemberontakan, 88.

34 Syekh Nawawi Banten, Mirqāh, 16.

${ }^{35}$ Ibid.

${ }^{36}$ Ibid.

${ }^{37}$ Amin, Sayyid Ulama, 36-37. Menurutnya, Syekh Nawawi Banten memang tidak berperan langsung merebut kemerdekaan tanah air, namun usahanya mendidik kader-kader anti penjajahan patut mendapatkan penghargaan. Ia dan kawankawannya menanamkan semangat juang melawan penjajahan dalam diri para murid yang nantinya pulang ke seluruh pelosok tanah air. Usaha mereka memancing kedatangan Snouck Hurgronje selaku penasihat pemerintah Hindia Belanda ke Mekah untuk menyelidiki cara kerja mereka.

38Ibnu Qoyim Isma'il, Kiai Penghulu, 37.

${ }^{39}$ Steenbrink, Beberapa Aspek, 118. Lihat

juga Mas'ud, Intelektual, 105.

40Snock, Mekka, 268-269.

41Dhofir, Tradisi, 132.

${ }^{42}$ Sri Mulyati, Sufism in Indonesia: Analysis of Nawawi al-Bantani's Salalim alFudala, (Canada: Institute of Islamic Studies McGill University, 1992), 21

43 Steenbrink, Beberapa Aspek, 118.

${ }^{44}$ Masa pembelajaran 9 tahun ini terbagi kedalam dua fase, yaitu fase pembelajaran bersama ayahnya yang berlangsung selama 3 tahun, dan fase pembelajaran dengan para kiai di daerah Jawa Barat yang berlangsung selama 6 tahun.

${ }^{45}$ Maragustam, Pemikiran Pendidikan Syekh Nawawi al-Bantani, (Yogyakarta: Datamedia, 2007), 106.

46Sri Mulyati, Sufisme in Indonesia, 34.

${ }^{47}$ Syekh Nawawi menyatakan motivasi menulisnya seperti ini di dalam mukadimah kitab Syarḥ Kāsyifah as-Sajā (2) dengan

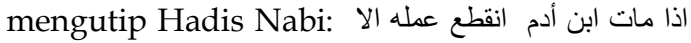
من ثلاث صدقة جارية أو علم ينتفع به أو ولد صالح يدعو له اله.

${ }^{48}$ Snouck Hurgronje, Mekka, 269. Lihat juga Amin, Sayyid Ulama, 43. Baca juga, Steenbrink, Beberapa Aspek, 118.

${ }^{49}$ Ibid.

${ }^{50}$ Mas'ud, Intelektual Pesantren, 111. Maragustam dalam bukunya: 'Pemikiran Pendidikan Syekh Nawawi al-Bantani, mengelompokkan kitab-kitab karya al-bantani menjadi enam bidang dengan beberapa penggabungan (107-108).

${ }^{51}$ Chaidar, Pujangga, 7.

${ }^{52}$ Ibid.

${ }^{53}$ Menurut Martin van Bruinessen (Kitab Kuning, 161), seluruh karya Syekh Nawawi ditulis dalam bahasa Arab.

54Maragustam, Pemikiran, 106.

55Sebagian besar karya Syekh Nawawi masih eksis dan dikaji di pesantren, utamanya pesantren salaf. Kitab-kitab tersebut yang paling banyak dipelajari adalah kitab tafsir alMunîr, Nihāyah az-Zein, Syarh Sullam at-Taufiq, Syarh 'Uqūd al-Lujain, Nașā'ịh al-'Ibād, Kāsyifah as-Sajā, Marāqi al-'Ubūdiyah dan Fath al-Majīd.

${ }^{56}$ Martin van Bruinessen, Kitab Kuning, Pesantren dan Tarekat, (Yogyakarta: Gading Publising), 2012.

57Dalam mukaddimah tafsir Marāh Labìd ia menyatakan keberaniannya untuk menulis kitab tafsirnya itu karena meneladani para pendahulunya dalam pen-tadwin-an kitab dan juga semangat untuk melestarikan ilmu pengetahuan.

${ }^{58}$ Dalam muqaddimah kitabnya, Nawawi selalu menyebutkan bahwa penulisan kitab yang dilakukannya dilakukan atas permintaan orang-orang dekatnya. Dalam pengantar kitab Bahjah al-Wasā'il misalnya, beliau mengatakan: "Sa'alani fihi $b a$ 'dh alAhibbah, fa Ajabtuh" (2), dalam muqaddimah Syarh Sullam al-Taufiq (2), beliau menyatakan: "Amarani Ba'dh al-A'izzah 'alā an Asyraha Syarhan Wajizzan....", dan ungkapan sejenisnya. 
Ungkapan ini menunjukkan kerendahan hati beliau sebagai seorang 'alim.

${ }^{59} \mathrm{Hal}$ ini diakuinya ketika menulis syarh kitab Tanqīh al-Qaul, syarh atas kitab Lubāb alHadīs, karya Imam as-Suyuṭī (Syekh Nawawi Banten, Tanqih al-Qaul, 2).

${ }^{60}$ Mas'ud, Intelektual, 109.

${ }^{61}$ Amin, Sayyid Ulama, 95-96. Baca juga Sartono Kartodirjo, Pemberontakan Petani Banten 1888, 280. Ia menambahkan satu nama yang juga merupakan pemimpin pemberontakan Banten, yaitu Haji Marjuki, yang merupakan keponakan dari Syekh Nawawi Banten. Namun, saat pemberontakan berlangsung, ia tidak berada di banten, karena telah berangkat ke Mekah beberapa bulan sebelum pecah pemberontakan, karena berbeda pandangan dengan Haji Wasith soal penentuan tanggal dimulainya pemberontakan.

${ }^{62}$ Mas'ud, Intelektual, 105.

${ }^{63}$ Maragustam, Pemikiran...., h. 108.

64 Ibid., h. 131.

${ }^{65}$ Abdurrahman Mas'ud, Intelektual Pesantren Perhelatan Agama dan Tradisi, (Yogyakarta: LkiS, 2004), h. 112.

${ }^{66} \mathrm{Abu}$ Abd al-Mu'thi Muhammad ibn Umar ibn Ali Nawawi al-Jawi al-Bantani alTanari (Selanjutnya disebut Nawawi), Nihayah al-Zein fi Irsyad al-Mubtadi'in, (Bandung: Syirkah al-Ma'arif, t.th.), h. 7.

67Syekh Muhammad Nawawi alBantani, Syarh Bahjah al-Wasa'il, (Indonesia: AlHaramain, t.th), h. 2. Dalam halaman muka kitab ini, penulisan nama Nawawi juga disertai dengan penyebutan tarekat yang diikutinya.

68Mas'ud, Intelektual...., hlm. 129-130.

69Syekh Nawawi, Nihāyah...., t.th., hlm.

3.

Zamakhsyari Dhofir, Tradisi Pesantren Studi Pandangan Hidup Kyai dan Visinya mengenai Masa Depan Indonesia, Jakarta: LP3ES, 2011, 132.

M. Bibit Suprapto, Ensiklopedi Ulama Nusantara Riwayat Hidup, Karya dan Perjuangan 157 Ulama Nusantara, Jakarta: Gelegar Media Indonesia, 2010.
Syamsul Munir Amin, Sayyid Ulama Hijaz Biografi Syaikh Nawawi al-Bantani, Yogyakarta: LkiS, 2009.

Abdurrahman Mas'ud, Dari Haramain ke Nusantara Jejak Intelektual Arsitek Pesantren, Jakarta: Kencana Prenada Media Group, 2006.

C. Snouck Hurgronje, Mekka in The Latter Part of 19TH Century Daily Life, Customs And Learning the Muslim of the East Indian Archipelago, Leiden: Late E. J. Brill LTD, 1931.

Chaidar, Sejarah Pujangga Islam Syaikh Nawawi al-Bantani Indonesia, Jakarta: CV Sarana Mulia, 1978.

M. Dien Majid, Berhaji di Masa Kolonial, Jakarta: CV Sejahtera, 2008.

Sri Mulyati, Sufism in Indonesia: Analysis of Nawawi al-Bantani's Salalim al-Fudala, Canada: Institute of Islamic Studies McGill University, 1992.

Maragustam, Pemikiran Pendidikan Syekh Nawawi al-Bantani, Yogyakarta: Datamedia, 2007.

Martin van Bruinessen, Kitab Kuning, Pesantren dan Tarekat, Yogyakarta: Gading Publising, 2012.

Al-Bantani, Syekh Nawawi, Kāsyifah asSajā Syarh Safinah an-Najā, Surabaya: Maktabah Syekh Muhammad bin Aḥmad Nabhan wa Aulādih, t.th.

Tanqìh al-Qaul al-Hasìis bi Syarh Lubāb al-Hadìs, Indonesia: al-Haramain, t.th.

Semarang: Pustaka al-Alawiyah, t.th. Bahjah al-Wasā'il bi Syarh alMasā'il, Indonesia: Al-Haramain, t.th. 
Tsaqofah \& Tarikh Vol. 2 No. 2 Juli-Desember 2017

Steenbrink, Kareel A., Beberapa aspek Tentang Islam di Indonesia Abad Ke- 19, Jakarta: Bulan Bintang, 1984.

Isma'il, Ibnu Qoyim, Kiai Penghulu Jawa Peranannya di Masa Kolonial, Jakarta: Gema Insani Press, 1997.

Kartodirdjo, Sartono, Pemberontakan Petani Banten 1888, Jakarta: Pustaka Jaya, 1984. 